\title{
真空浸炭中の炭素侵入機構
}

\author{
森田敏之* 1 ，井上幸一郎*2，羽生田智紀*1
}

\section{Mechanism of Carbon Infiltration in Vacuum-Carburizing Process}

\author{
Toshiyuki Morita, Koichiro Inoue, and Tomoki Hanyuda
}

\section{Synopsis}

In order to estimate carbon distribution in vacuum carburized steels, the mechanism of the introduction of carbon into steel during the process was investigated. Steels bearing various amounts of Si and Cr were machined to specimens with $0.1 \mathrm{~mm}$ thickness, which was considered to be the surface area of carbrized parts. They were vacuum carburized at the temperature range of $1123 \mathrm{~K}$ to $1323 \mathrm{~K}$ for sufficient long time to obtain uniform microstructures and then quenched. Using Fe-Graphite diagram of each steel grade, it was clarified that the measured carbon content of each specimen corresponded to the carbon content at which graphite begins to form. And the area fraction of carbide in structures was also almost the same value calculated with the diagram. From these results, we concluded that graphite is generated from carburizing gas onto the surface of steel, and carbon is introduced into the steel under local equilibrium between the steel surface and the graphite at a treating temperature.

\section{1. 緒言}

浸炭焼入は代表的な鋼の表面硬化処理である. 現在, 一 般的に行われている, 浸炭性ガスのブードア反応を利用し て鋼中に炭素を侵入させるガス浸炭に代わって，500～ $2000 \mathrm{~Pa}$ 程度の炭化水素ガス中に鋼材を保持し同ガスを炭 素の供給源とする真空浸炭が普及し始めている. 真空浸炭 はガス浸炭で生じる粒界酸化が発生しない, 高温浸炭が実 施しやすいなど短時間で高品位の浸炭処理が可能な利点 がある1) 4).

ガス浸炭では雲囲気を構成するガスと鋼材表面が平衡 するため, 雲囲気ガスの分圧を制御して表面炭素濃度を調 整している。ここで処理品の鋼材成分が変化しても，組成 から計算できる鋼中の炭素の活量を考慮すれば, 表面炭素 濃度を正確に推定することが可能である ${ }^{4)}$. 表面から鋼中 に侵入した炭素は拡散方程式にしたがって鋼中内部に拡 散する。このため, 䨌囲気分圧と平衡する表面炭素濃度を 精度良く予測し, 拡散方程式を解いて内部への拡散挙動を 計算すれば，部品形状や鋼種によらず，正確に炭素濃度分
布を求めることができる.

ガス浸炭が処理中に連続的に雰囲気制御するのに対し て, 真空浸炭では, 炭化水素ガス雲囲気中に保持し炭素を 侵入させる浸炭期と, 真空にして炭素を鋼材内部へ拡散さ せる拡散期に分かれる.拡散期では鋼材表面からの炭素の 侵入がないため, 浸炭期に過剰に導入された炭素を鋼材内 部に拡散させることになる.

ここで, 真空浸炭の浸炭期における表面炭素濃度変化を 予測できれば, 浸炭期と拡散期の時間を変化させることで 拡散期の後に所望とする炭素濃度分布を得られるはずで ある。

ところが実際の真空浸炭炉操業では, 浸炭条件は試行錯 誤のうえ決定しており, 鋼材成分や部品形状が変化した場 合にはあらためて条件を見直す必要があった。

これは, 現状では真空浸炭中の鋼材の表面炭素濃度を予 測することが困難であり, その理由として浸炭機構が明確 でないことと処理温度や鋼種の影響が不明であることが 挙げられる.たとえば, 真空浸炭後に観察される鋼材の表 面炭素濃度や析出炭化物について次のような種々の説が 
あり，統一的な原理で説明することができていない. (1)表 面炭素濃度は Acm 線上となり, セメンタイト（以下 $\theta$ ) は生成しない5), (2)表面が完全に炭化物に覆われ，表面炭 素濃度は $6.7 \%$ となる ${ }^{6)}$. (3)雲囲気との平行反応で浸炭が 生じ, 雲囲気ガスの分圧制御で表面の炭素濃度が制御可能 7)などである。

以上から, 本研究の目的は真空浸炭材の表面炭素濃度制 御方法を確立するために, 真空浸炭中の鋼材表面の状態を 明らかにすることとした。

\section{2. 実験方法}

本研究に用いた試験片は, 厚さ $0.1 \mathrm{~mm}$ の薄板である. この試験片は板厚が炭素の拡散距離と比較して十分に薄 く厚さ方向の炭素濃度分布を無視することができるため, 断面全体を浸炭表面と同じ状態とみなし観察を行った。

供試材は純度 $99.9 \%$ の純鉄，または JIS SCr420を基本 成分として, Si,Cr 添加量を変化させた 5 鋼種である. Table 1 に供試材の化学成分を示す。供試材は高周波誘導炉を用 いて真空中で溶解し， $30 \mathrm{~kg}$ 鋼塊に鋳造した後，1523 K で 熱間鍛造し $\phi 30 \mathrm{~mm}$ とした.これを厚さ $0.1 \mathrm{~mm}$ に冷間圧 延し, $1 \mathrm{~Pa}$ の真空下で $1223 \mathrm{~K}, 3.6 \mathrm{ks}$ 保持後空冷して試験 片とした.浸炭には大同特殊鋼(株製プラズマ浸炭ガス冷炉 を用い，原料ガスとしてプロパンを用いた。浸炭は Table 2 に示す条件で行った．浸炭処理後，組織を凍結するため 浸炭温度から $3 \mathrm{bar}$ 窒素雲囲気にて直接ガス焼入れした。 EPMA を用いた炭素濃度の測定, 光学顕微鏡を用いた組織 観察に供した.

\section{3. 実験結果}

Fig. 1 に真空浸炭した薄板状試験片の代表的な組織を示 す.腐食には $5 \%$ ナイタール溶液を用いた. 試験片表面の 白色層は試験片保護のための Ni メッキである。写真右下 の数字は炭化物面積率の実測值を表す.

試験片を薄板にすることによって, Steel E を除いていず れの浸炭条件でも中心まで均一な組織が得られている.

純鉄では, いずれの温度で浸炭を行った場合でも炭化物 はパーライト状もしくは粒界に薄く析出している.浸炭中 に炭化物が析出すると, 塊状, あるいは粒界に数 $\mu \mathrm{m}$ 程 度の厚さに網目状の形態になる6) ことから, 本実験で観 察された炭化物はガス冷却中に析出したものである.すな わち, 純鉄は浸炭中にはオーステナイト（以下 $\gamma$ ) 単相 であったと考えられる。

Steel A では本処理温度域ではマルテンサイトとパーラ イトの混合組織が得られた. 純鉄と同様に浸炭時の析出炭 化物は存在せず， $\gamma$ 単相であったと考えられる。ママルテ ンサイトの生成は Steel A の焼入性が純鉄よりも高いこと による。

Steel B には 1123 K では浸炭中に生成したと考えられる 粗大な炭化物が観察され, 浸炭中は $\gamma$ と $\theta$ の 2 相組織で

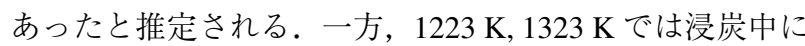
生成したと考えられる炭化物は観察されず，浸炭中は $\gamma$ 単相である。

Steel C, Steel D では温度によらず浸炭中に生成したと考 えられる粗大な炭化物が存在し, 浸炭中は $\gamma$ と $\theta$ の 2 相

Table 1. Chemical composition of materials (mass\%).

\begin{tabular}{c|c|c|c|c|c|c|c|c|c|c|c}
\hline Grade & $\mathrm{C}$ & $\mathrm{Si}$ & $\mathrm{Mn}$ & $\mathrm{P}$ & $\mathrm{S}$ & $\mathrm{Cu}$ & $\mathrm{Ni}$ & $\mathrm{Cr}$ & $\mathrm{Mo}$ & $\mathrm{N}$ & $\mathrm{O}$ \\
\hline Pure iron & $<0.01$ & $<0.01$ & $<0.01$ & $<0.010$ & $<0.010$ & $<0.01$ & $<0.01$ & $<0.01$ & $<0.01$ & $<0.01$ & $<0.01$ \\
\hline Steel A & 0.2 & 1.8 & 0.8 & 0.013 & 0.018 & 0.10 & 0.05 & 0.5 & $<0.01$ & 0.014 & 0.001 \\
\hline Steel B & 0.2 & 1.5 & 0.8 & 0.022 & 0.014 & 0.10 & 0.05 & 0.7 & $<0.01$ & 0.014 & 0.001 \\
\hline Steel C & 0.2 & 0.8 & 0.8 & 0.008 & 0.012 & 0.10 & 0.05 & 0.8 & $<0.01$ & 0.016 & 0.001 \\
\hline Steel D & 0.2 & 0.2 & 0.8 & 0.006 & 0.008 & 0.10 & 0.05 & 1.0 & $<0.01$ & 0.015 & 0.001 \\
\hline Steel E & 0.2 & $<0.01$ & $<0.01$ & 0.010 & 0.011 & $<0.01$ & $<0.01$ & 4.9 & $<0.01$ & 0.016 & 0.001 \\
\hline
\end{tabular}

Table 2. Conditions of carburizing.

\begin{tabular}{c|c|c|c}
\hline Temperature & Holding time & Propane flow & Quenching \\
\hline $1123 \mathrm{~K}$ & $259.2 \mathrm{ks}$ & $7 \mathrm{dm}^{3} / \mathrm{s}$ & 3 bar $N_{2}$ \\
\hline $1223 \mathrm{~K}$ & $172.8 \mathrm{ks}$ & $10 \mathrm{dm}^{3} / \mathrm{s}$ & 3 bar $N_{2}$ \\
\hline $1323 \mathrm{~K}$ & $86.4 \mathrm{ks}$ & $13 \mathrm{dm}^{3} / \mathrm{s}$ & 3 bar $N_{2}$ \\
\hline
\end{tabular}




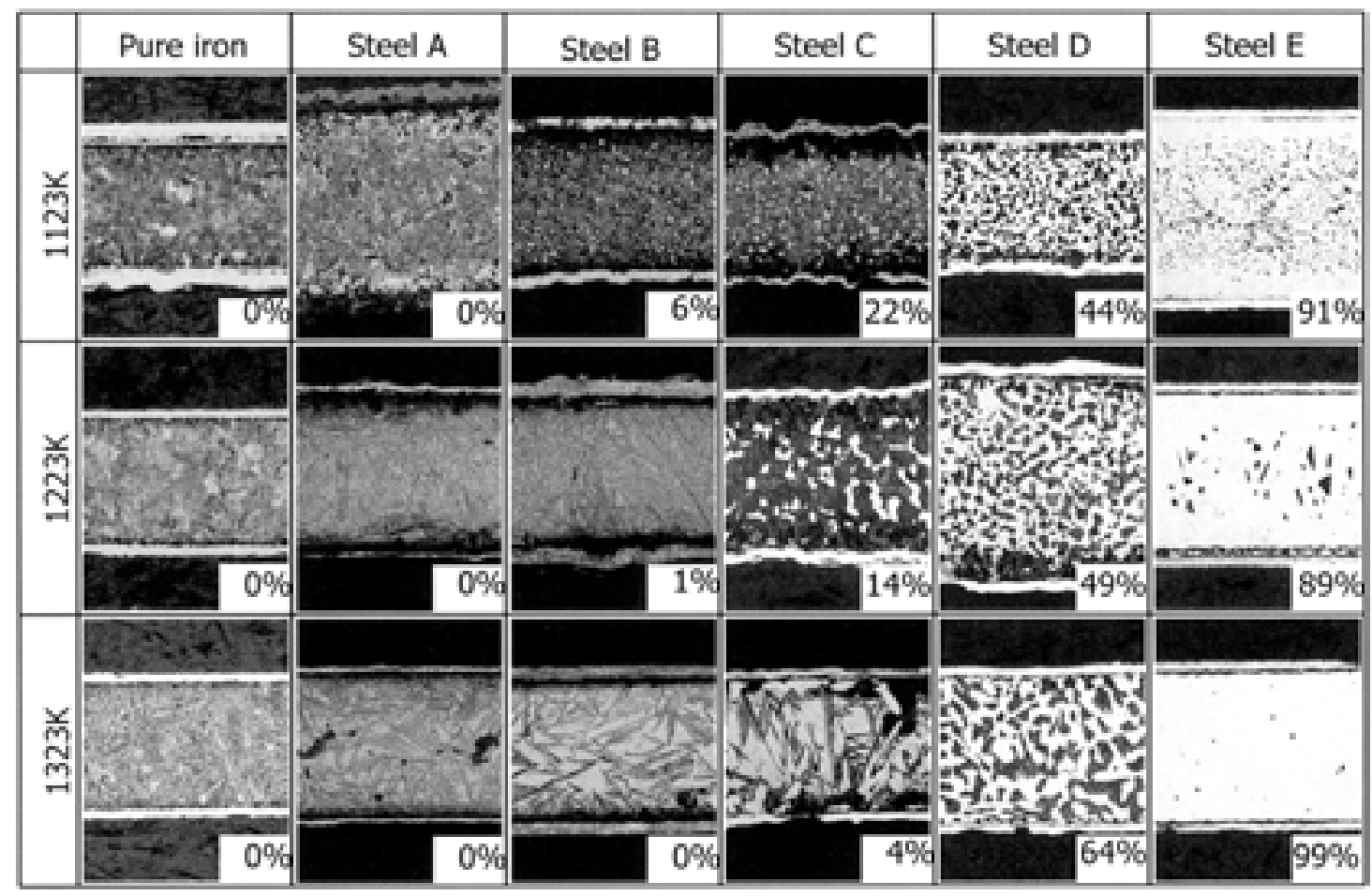

$\underline{100 \mu m}$

Fig.1. Microstructures of vacuum-carburized specimens.

組織と考えられる。

Steel E では均一な組織が得られた $1323 \mathrm{~K}$ 処理材はナイ タールに全く腐食されない炭化物単相の組織となった。こ の試験片はX 線回折によりほぼ $\theta$ 単相であることを確認 している.より低温度で処理した試験片には中央付近に パーライトが生成しており，焼入直前には表面が $\theta$ に覆 われ中央付近に $\gamma$ が残存している不均一な組織であった と考えられる。

炭素は $\gamma$ 中では侵入型固溶原子であるが， $\theta$ 中では規 則格子をなしているため $\theta$ 中での拡散速度は $\gamma$ 中に比べ 遅い. Steel E では表面が完全に $\theta$ で覆われているため他 の試料と比較して試験片中央への炭素の供給が遅く,均一 な組織を得るにはより長い時間が必要となる。したがっ て，1223 K 以下で浸炭した試験片では，均一な組織を得 られなかったと考えられる。

\section{4. 考察}

Fig.2 に各成分の計算状態図を示す。計算には熱力学計 算ソフト Thermo-Calc ${ }^{8)}$ を用い, データベースとして SGTE Solution database ver. $2^{9)}$ を用いた。

黒鉛を含めた計算を鉄一炭素系で行うと，，は は準安定 相であるため状態図上には現れないが，多成分系では $\theta$
に Cr などの合金元素が固溶することでエネルギーが低下 するため，成分によっては $\theta$ が計算状態図中に表れるこ とがある. 今回の実験に用いた鋼では, Steel B F で状 態図上に $\theta$ と黒鉛の両方が現れている. 図中○今回実 験を行った温度での黒鉛が析出する炭素濃度の計算值を, $\triangle$ வ浸炭を行った薄板の炭素濃度の実測值を表す.

純鉄では鉄 - 黒鉛系が安定であるため, 今回実験を行っ た全ての温度で黒鉛と平衡する相は $\gamma$ 単相となる. Steel A も純鉄と同様に黒鉛と平衡する相は常に $\gamma$ 単相である. Steel B は $1273 \mathrm{~K}$ 以上では黒鉛と平衡する相が $\gamma$ 単相で あるが， $1273 \mathrm{~K}$ 以下では $\gamma, \theta$ の 2 相と平衡する. Steel C, Steel D では全温度で黒鉛と平衡する相が $\gamma, \theta$ の 2 相 となる. Steel E では黒鉛と平衡する相は全温度で $\theta$ 単相 となる。

これらの計算結果は, Fig.1 に示す浸炭中の炭化物の有 無と一致している. Fig.3に計算した黒鉛と平衡する状態 での炭化物量, 炭素濃度と実験結果との比較を示す. 計算 值と実測值はよく一致する。このことから, 真空浸炭の炭 素浸入機構は, 鋼材表面で浸炭ガスの分解により黒鉛が生 成し, 黒鉛が鋼材に吸収されることであり, 鋼材表面は黒 鉛と平衡しているものと推察される.

鋼材表面が黒鉛と平衡していることを確認するために， 
Steel A, Steel D, Steel E の薄板状試験片に黒鉛を密着させ て $0.1 \mathrm{~Pa}$ の減圧下で $1223 \mathrm{~K}, 172.8 \mathrm{ks}$ 保持後ガス焼入を行 い，組織を真空浸炭材と比較した．結果を Fig.4 に示す. 写真右下の数字は炭化物面積率の実測值である.

この実験でも薄板上の試料を用いることによって均一 な組織が得られている. Steel A はマルテンサイトとパー ライトの混合組織であり, 真空浸炭品と同様の組織を呈し ている. Steel D は粗大な炭化物が $50 \%$ 程度の面積率を占 めており,熱処理中は $\gamma$ と $\theta$ の 2 相組織であると考えら れ，真空浸炭組織に酷似している。さらに Steel E はナイ タールに全く腐食されない炭化物単相であり, 熱処理中も
同じ組織であったと考えられる.

以上の真空浸炭材の組織, 黒鉛との平衡を仮定した熱力 学計算, および黒鉛と接触させた状態での真空熱処理の組 織観察結果が一致したため, 真空浸炭中の表面では, 黒鉛 と鋼材の局所平衡が成立していると結論づけられる。

本研究の結果をもとに, 緒言に述べたこれまでに得られ ている実験結果 5)～7) について考察する. (1)奥宮ら 5) は, 表面炭素濃度は Acm 線上となり，，は生成しないとの実 験結果を報告しているが, 純鉄や $\mathrm{S} 20 \mathrm{C}$ などの $\mathrm{Cr}$ 添加量 の低い, Fig.2(a)(b) のように状態図上に $\theta$ が現れない鋼 を実験に用いている。このため, 真空浸炭中に $\theta$ が生成
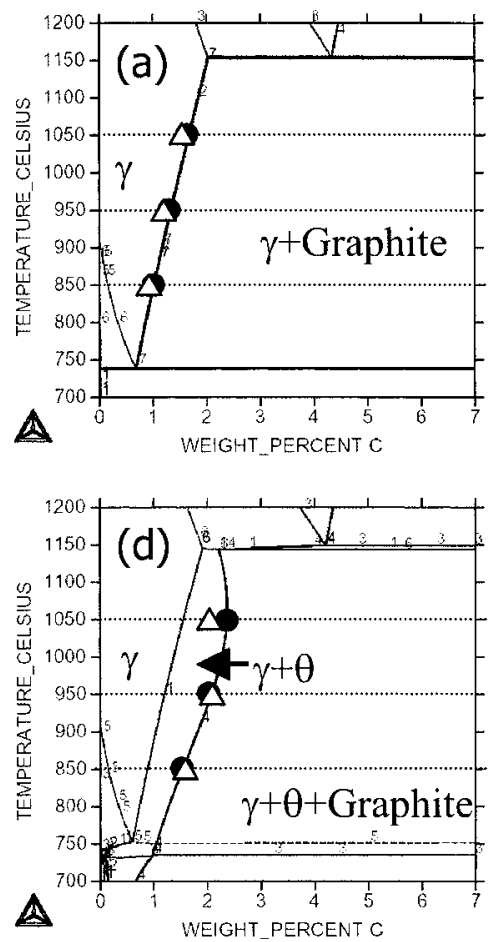
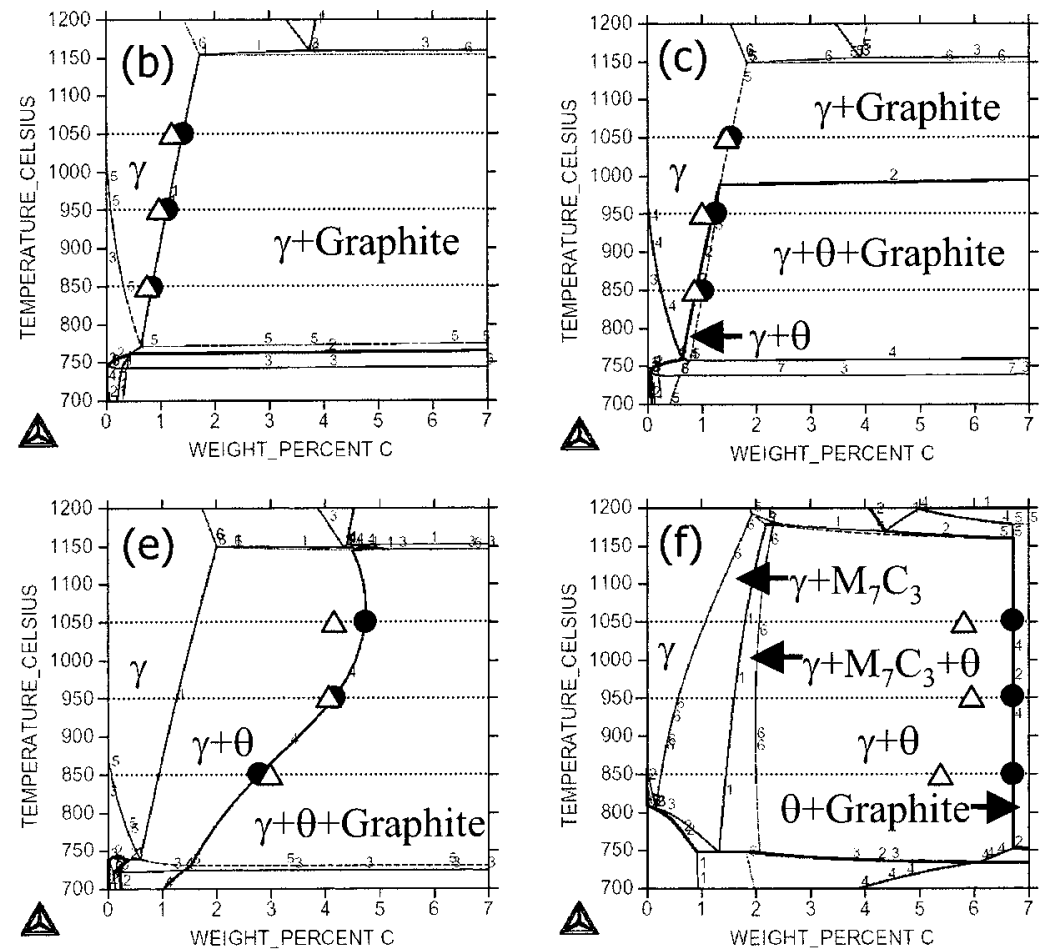

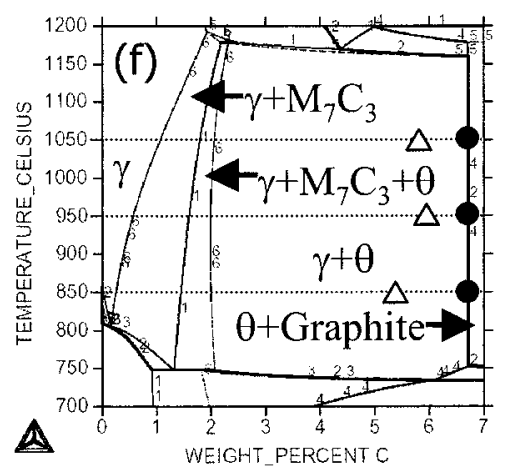

Fig.2. Calculated phase diagrams (a)Pure iron, (b)Steel A, (c)Steel B, (d)Steel C, (e)Steel D and (f)Steel E.
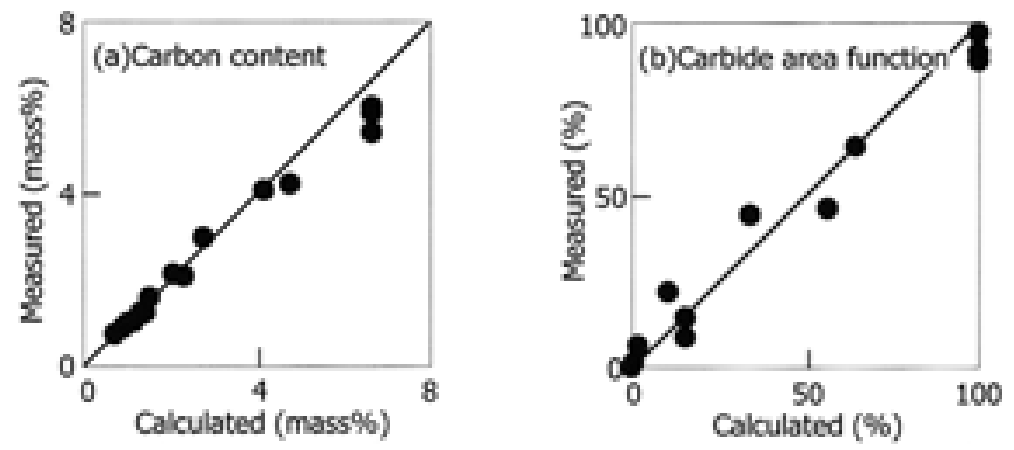

Fig.3. Carbide area fraction and carbon content of $0.1 \mathrm{~mm}$ thick specimens for materials shown in Table 1. Carburizing conditions are shown in Table 2. 


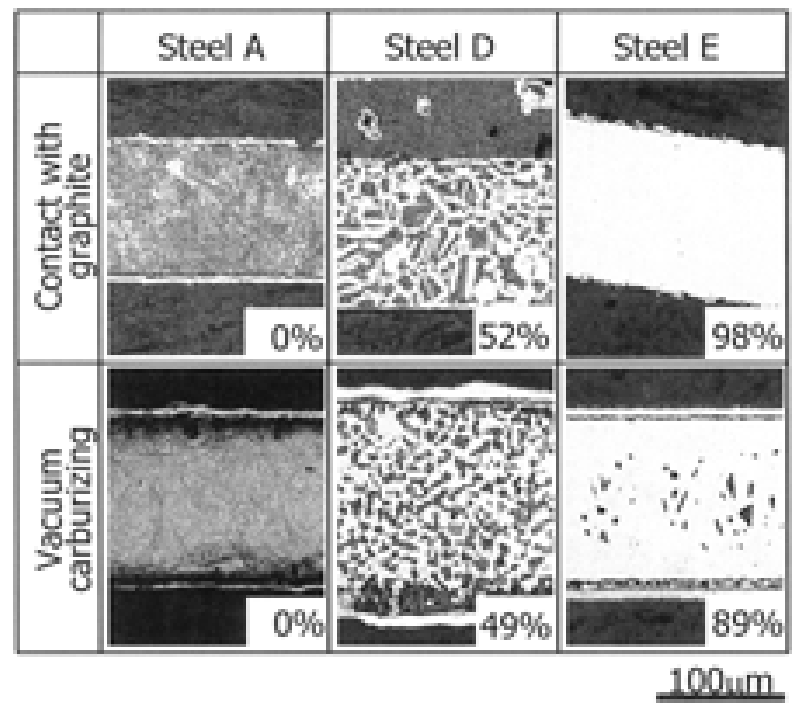

Fig.4. Microstructures of specimens contacted with graphite at $172.8 \mathrm{ks}$ for $1223 \mathrm{~K}$ and vacuum carburized at $172.8 \mathrm{ks}$ for $1223 \mathrm{~K}$.

しなかったと考えられる。(2)井上ら 6) は，実験に SCr420 などの丸棒を用い，真空浸炭した表面の $70 \%$ 程度が炭化 物に覆われていたことを報告している。 Thermo-Calc を用 いた計算によると炭化物面積率は $60 \%$ 程度であり、これ は井上らの実験結果と近い值である。(3)河田らは7) エチ レンを浸炭ガスとして用いた研究により, 雲囲気との平衡 反応で浸炭が生じ, 䨌囲気ガスの分圧制御で表面の炭素濃 度が制御可能と結論している. 本研究とは浸炭ガスが異な るため, 他の浸炭ガス種への本研究結果の適用については 検討が必要と考えられる。

\section{5. 結言}

（1）真空浸炭中の表面には炭化物が生成しており，その量 は被処理材の成分によって 0 から $100 \%$ まで変化する.

(2) 真空浸炭中の炭化物量および炭素濃度は黒鉛との平衡 を仮定した熱力学計算結果と一致し, 真空浸炭中の被処理 材表面は黒鉛と平衡している.

(3) これまでに報告されている, 真空浸炭中の炭化物が生 成に関する実験結果の多くは, 本研究の知見を用いて説明 可能である.

(文 献)

1) 杉山道生:熱処理, 37(1997), 154.

2) 町 哲司:熱処理, 45(2005), 80.

3) 下里吉計:工業加熱, 39(2002), 21.

4) K.Takada, T.Inoue and K.Kaneko, T.Toyoda: Kobe Steel Eng. Rep., 32(1982), 66.
5）奥宮正洋,新美格, 恒川芳樹,門谷政幸:第31回日本熱処 理技術協会講演大会講演概要集 (1990), 29.

6）井上洋介, 井上吉弘:第58回日本熱処理技術協会講演大 会講演概要集 $(2004), 1$.

7）河田一喜:熱処理, 44(2004), 289.

8) B.Sundman, B.Jansson:CALPHAD, 9(1985), 153.

9) I.Ansara and B.Sundman : Compuer Handling and Dissemination of Data, ed. by P.S.Glaeser, (1987), 154. 